\section{Some Factors Influencing Tolerance to Moisture Stress of Three Range Grasses ${ }^{1}$}

\section{EDWARD F. SCHLATTERER ${ }^{2}$ AND M. HIRONAKA}

Graduate Assistant and Associate Professor, College of Forestry, Wildlife and Range Sciences, University of Idaho, Moscow.

\section{Highlight}

Pre-conditioning of bluebunch wheatgrass, squirreltail and Thurber stipa plants by exposure to different temperatures and watering schedules affected their tolerance to moisture stress. Plants conditioned under high or low temperatures were more resistant to moisture stress than plants conditioned at moderate temperature. Plants grown in fertile mound soil werc less conditioned to withstand moisture stress than those grown in less fertile intermound soil.

In the drier portion of the sagebrush-grass region, establishment of squirreltail (Sitanion hystrix (Nutt.) J. G. Smith), bluebunch wheatgrass (Agropyron spicatum (Pursh.) Scribn. and Smith), and Thurber stipa (Stipa thurberiana Piper) appears to be related to microsite conditions (Schlatterer, 1968). Over extensive areas where these species occur, the microtopography is characterized by low mounds coincident with the distribution of sagebrush. Sagebrush is, or was, a primary factor in the

${ }^{1}$ This study was supported in full by the Forest, Wildlife and Range Experiment Station, University of Idaho, Moscow, Idaho. Received September 10, 1971.

2 Present address is Ecologist, Regional Office, U.S. Forest Service, Ogden, Utah. genesis of these mounds. The mounds are raised 2 to $15 \mathrm{~cm}$ in height above adjoining surface levels and their diameter is frequently less than a meter but may reach 2 or more meters where they have coalesced. Microsite conditions of mound and intermound positions are quite different. The intermound position has a harsher micro-environment, a soil that is less fertile and contains less available moisture for plant growth than does the adjacent mound. Nonetheless, squirreltail is found to establish more frequently in the intermound position even when competition from sagebrush is removed in a depleted Artemisia tridentata subsp. wyomingensis/Stipa thurberiana community (Schlatterer, 1968). This is contrary to what would be expected on the basis of available soil moisture.

Successful establishment in regions of low rainfall occurs when a plant is able to withstand the severity of its environment. Resistance or tolerance to moisture stress is genetically inherited and to some degree can be induced by pre-conditioning (McAlister, 1944; Levitt, 1956).

This paper deals with the influence of soil, temperature, moisture and genetic inheritance on conditioning response to moisture stress of 3 perennial range grasses.

\section{Methods}

The upper $15 \mathrm{~cm}$ of mound and intermound soils from a depleted Artemisia tridentata subsp. wyomingensis/Stipa thurberiana community was used for the experiment. The soil, Minidoka silt loam, was developed from loessial parent material.

Seed sources for seedlings were as follows: squirreltailCassia County, Idaho, elevation $1310 \mathrm{~m}$; bluebunch wheatgrass-Minidoka and Twin Falls Counties, Idaho, elevations 
$1280 \mathrm{~m}$ and $1675 \mathrm{~m}$, respectively; Thurber stipa-Minidoka and Owyhee Counties, Idaho, $1280 \mathrm{~m}$ and $1675 \mathrm{~m}$, respectively. Annual precipitation at lower elevation sites averages less than $250 \mathrm{~mm}$, while sites at the higher elevations receive about $400 \mathrm{~mm}$ of precipitation.

Seedlings were grown in $950 \mathrm{cc}$ plastic cylindrical containers, $14.5 \mathrm{~cm}$ tall and $11 \mathrm{~cm}$ top diameter. After emergence, the number of seedlings were reduced to 2 per pot from a maximum of 5 . A total of 240 pots were involved.

Experimental treatments included: 5 seed sources, 2 soils, 3 temperature regimes and 2 watering schedules. There were 4 replicates comprised of 8 individuals.

The duration of the experiment extended from October to April. Average greenhouse temperatures were $29.4 \mathrm{C}$ and $12.8 \mathrm{C}$ during the day and night periods, respectively. "Grolux" fluorescent lighting supplemented natural light during the 14-hour daylength. Pot positions were periodically rotated in a systematic manner.

Scedlings were grown in the greenhouse for a period of 8 weeks before temperature treatments were initiated. After measuring shoot height of all plants, one-third of the seedlings was transferred to a growth chamber with a 14-hour day temperature of $18.3 \mathrm{C}$ and 10-hour night temperature of 1.7 C for a 3-week period. Another one-third of the seedlings was placed in a second growth chamber for the same period under similar conditions except the day temperature was maintained at $32.2 \mathrm{C}$. The remaining lot of seedlings was left in the greenhouse as a control.

One-half of all pots received water every fifth day during the first eleven weeks. The remaining one-half of the pots was watered every tenth day. Water was supplied until the soil was saturated.

After a 3-week period in the growth chamber, all plants were clipped $1.0 \mathrm{~cm}$ above the crown and watered. Water was withheld from all plants for a 5-week period before regrowth was clipped and weighed. All pots were watered immediately after the second clipping and again for the last time one week later, after which regrowth was clipped weekly for four weeks.

The experiment was repeated under similar conditions except that the plants were 11 wceks old instead of 8 weeks when they were placed in the growth chamber. This delay of 3 weeks resulted in initiating the 5-week moisture stress period when the plants were 14 weeks of age instead of 11 weeks.

Statistical analyses of data were made by analysis of variance and Duncan's new multiple range test.

\section{Results and Discussion Mound Versus Intermound Soils}

Vigor of seedlings in mound soil was greater than for seedlings from intermound soil during the first eleven weeks (Table 1). At the end of 8 weeks shoot height differences were as much as $2.5 \mathrm{~cm}$ to $4.0 \mathrm{~cm}$ greater for plants grown in mound soil. At the end of the 11th week, top weight differences ranged from $.035 \mathrm{~g}$ to $.085 \mathrm{~g}$ greater per plant for the 3 species on mound soil. The difference in vigor as suggested by plant height and weight was attributed to higher nutrient availability, particularly nitrogen, as well as a more favorable root environment provided by the mound soil (Table 2 ).
Table 1. Mean height $(\mathrm{cm})$ of scedlings grown on two types of soil before temperature conditioning ( $8 \mathrm{wks}$ ) and the mean shoot weight ( $g$ ) of seedlings after temperature conditioning period (11 wks).

\begin{tabular}{|c|c|c|c|c|c|c|}
\hline \multirow{2}{*}{$\begin{array}{c}\text { Soil } \\
\text { Type }\end{array}$} & \multicolumn{2}{|c|}{ Squirreltail } & \multicolumn{2}{|c|}{$\begin{array}{l}\text { Bluebunch } \\
\text { wheatgrass }\end{array}$} & \multicolumn{2}{|c|}{ Thurber stipa } \\
\hline & Height & Weight & Height & Weight & Height & Weight \\
\hline $\begin{array}{l}\text { Mound } \\
\text { Inter- }\end{array}$ & $35.17 \mathrm{a}^{*}$ & $.320 \mathrm{a}$ & $40.90 \mathrm{a}$ & $.257 \mathrm{a}$ & $31.64 \mathrm{a}$ & $.197 \mathrm{a}$ \\
\hline mound & $32.28 \mathrm{a}$ & $.235 \mathrm{a}$ & $36.82 \mathrm{a}$ & $.209 \mathrm{a}$ & $28.96 \mathrm{a}$ & $.161 \mathrm{a}$ \\
\hline
\end{tabular}

* Values designated by different letter symbols are significantly different at the $95 \%$ probability level.

Reversal in growth response occurred during the 5-week moisture stress period. Plants on the less fertile intermound soil produced more regrowth than those on mound soil (Table 3). This reversal was consistent for all three species but statistically significant for only squirreltail and bluebunch wheatgrass.

The conditioning of plants to moisture stress was affected by soil. The normally higher producing soil of the mounds developed plants that were less tolerant to moisture stress than those

Table 2. A comparison $(\overline{\mathbf{x}} \pm s)$ of some of the important soil characteristics of the surface $15 \mathrm{~cm}$ of mound and intermound soil from the Castleford site, Twin Falls County, Idaho.

\begin{tabular}{|c|c|c|c|}
\hline $\begin{array}{c}\text { Soil } \\
\text { property }\end{array}$ & Intermound & Mound & $\begin{array}{l}\text { " } t \text { " test } \\
\text { significan }\end{array}$ \\
\hline $\begin{array}{l}\% \text { aggregation } \\
\text { below } 2 \mathrm{~mm} \text { in } \\
\text { size }\end{array}$ & $15.62 \pm 3.64$ & $19.84 \pm 2.49$ & * \\
\hline $\begin{array}{l}\text { Hydraulic } \\
\text { conductivity } \\
\text { (cm/min) }\end{array}$ & $.0192 \pm .0081$ & $.0399 \pm .0123$ & $* *$ \\
\hline$\%$ nitrogen & $.093 \pm .006$ & $.136 \pm .016$ & $* *$ \\
\hline $\begin{array}{l}\text { Potassium } \\
\text { kilo/hectare }\end{array}$ & $677.0 \pm 24.2$ & $1087.2 \pm 11.0$ & ** \\
\hline $\begin{array}{l}\text { Phosphorus } \\
\text { kilo/hectare }\end{array}$ & $13.1 \pm 2.5$ & $20.7 \pm 7.3$ & ns \\
\hline $\begin{array}{l}\text { Magnesium } \\
\mathrm{meg} / 100 \mathrm{~g}\end{array}$ & $3.47 \pm .15$ & $3.71 \pm .33$ & ns \\
\hline $\begin{array}{l}\text { Exchange capacity } \\
\mathrm{meg} / 100 \mathrm{~g}\end{array}$ & $18.42 \pm 1.23$ & $21.00 \pm .88$ & ** \\
\hline $\begin{array}{l}\text { Calcium } \\
\mathrm{meg} / 100 \mathrm{~g}\end{array}$ & $10.31 \pm .97$ & $12.18 \pm .73$ & * \\
\hline $\begin{array}{l}\text { Sodium } \\
\text { meg/100 g }\end{array}$ & $.59 \pm .13$ & $.76 \pm .20$ & ns \\
\hline $\begin{array}{l}\text { Electrical } \\
\text { conductivity } \\
\text { mho/cm }\end{array}$ & $.76 \pm .06$ & $1.32 \pm .28$ & ** \\
\hline
\end{tabular}

* Significant at the 95 percent probability level. ** Significant at the 99 percent probability level. 
grown on the less productive soil of the intermound positions.

\section{Effect of Different Rates of Watering}

Saturation every 10 days had a greater conditioning effect than saturation every 5 days for all three species. The difference was statistically significant for all species except Thurber stipa. Low water supply induced a more favorable conditioning effect than a high water supply. The pots were weighed periodically and at no time was the soil moisture stress above the 15 atmosphere level for either group. It is apparent, therefore, that this conditioning effect can occur even when soil moisture stress is not great enough to produce wilting.

\section{Effect of Temperature Stress}

The results of temperature conditioning were striking. In all cases the production of regrowth by the greenhouse control was lower than for the groups conditioned at either high or low temperatures. This suggests that deviation from the daynight temperature pattern that occurred under greenhouse conditions was effective in inducing resistance to moisture stress. Because the magnitudes of diurnal fluctuation in the cool growth chamber and in the greenhouse were both $16.6 \mathrm{C}$, the greater resistance induced in plants in the growth chamber was primarily attributed to the lower temperatures to which the plants were exposed. However, two other factors in the environment of the growth chambers may have aided in inducing greater resistance. Plants in the growth chambers were under the influence of a "wind," artificially created to maintain constant circulation of air and minimum fluctuation in temperature. Also, the lighting in the growth chamber while adequate for photosynthesis was of distinctly different quality than that in the greenhouse.

Evidence of unfavorable growing conditions in the growth chambers were noted. Plants in the growth chambers all developed necrotic leaf tips and a distinct reddish-purple cast especially at the stem base and on the lower leaves. Older leaves began to yellow and die. These symptoms have been reported in barley as the result of either a nitrogen or phosphorus deficiency (Wallace, 1961). The additional stresses induced by the constant drying winds of the growth chamber and the lower quality of light probably contributed to the conditioning process.

Weight of regrowth of the warm conditioned Thurber stipa and squirreltail was greater than the weight of regrowth produced by the cold conditioned plants. These differences were statistically significant for squirreltail and nearly so for Thurber stipa. No difference was detected for bluebunch wheatgrass.
Table 3. Mean weight (g) of regrowth per plant after five weeks of soil moisture stress.

\begin{tabular}{|c|c|c|c|}
\hline \multirow[b]{2}{*}{ Item } & \multicolumn{3}{|c|}{$\begin{array}{l}\text { Weight of } \\
\text { regrowth }\end{array}$} \\
\hline & Squirreltail & $\begin{array}{l}\text { Bluebunch } \\
\text { wheatgrass }\end{array}$ & $\begin{array}{l}\text { Thurber } \\
\text { stipa }\end{array}$ \\
\hline \multicolumn{4}{|l|}{ Soil } \\
\hline Mound & $.674 \mathrm{a}^{*}$ & $.282 \mathrm{a}$ & $.133 \mathrm{a}$ \\
\hline Intermound & $.773 \mathrm{~b}$ & $.451 \mathrm{~b}$ & $.229 \mathrm{a}$ \\
\hline \multicolumn{4}{|l|}{ Watering sequence } \\
\hline Every 5 days & $.627 \mathrm{a}$ & $.277 \mathrm{a}$ & $.115 \mathrm{a}$ \\
\hline Every 10 days & $.820 \mathrm{~b}$ & $.456 \mathrm{~b}$ & $.247 \mathrm{a}$ \\
\hline \multicolumn{4}{|c|}{ Temperature conditioning } \\
\hline Cold & .775 a & $.454 \mathrm{a}$ & $.181 \mathrm{ab}$ \\
\hline Warm & $.888 \mathrm{~b}$ & $.458 \mathrm{a}$ & $.257 \mathrm{a}$ \\
\hline Control & $.508 \mathrm{c}$ & $.187 \mathrm{~b}$ & $.105 \mathrm{~b}$ \\
\hline \multicolumn{4}{|l|}{ Plant source } \\
\hline Low elevation & - & $.368 \mathrm{a}$ & $.202 \mathrm{a}$ \\
\hline High elevation & - & $.365 \mathrm{a}$ & $.159 \mathrm{~b}$ \\
\hline
\end{tabular}

Effect of Seed Source and Species

Thurber stipa from the lower elevation seed source, a product of more xeric conditions, outproduced those from the high elevation seed source, a product of a more mesic environment (Table 3 ). There were no significant differences in the response of bluebunch wheatgrass from the two seed sources.

Squirreltail plays a seral role in the sagebrushgrass community studied, and is a minor constituent of the ultimate stable community. It is a shorter lived species than either Thurber stipa or bluebunch wheatgrass. Although squirreltail is taxonomically closely related to bluebunch wheatgrass, it was expected to respond differently in this study due to its differing ecologic role. In most cases, however, the response of both squirreltail and bluebunch wheatgrass were similar.

Thurber stipa has a morphology different from either bluebunch wheatgrass or squirreltail. Its most obvious characteristic is its tightly rolled leaves. Such a characteristic is effective in reducing transpirational losses when soil moisture is in short supply (Oppenheimer, 1960). Following the 5 weeks of soil moisture stress, it was noted that a considerably higher proportion of the Thurber stipa leaves remained green as compared to bluebunch wheatgrass and squirreltail (53\% as opposed to 28 and $34 \%$, respectively). The subsequent poor response of Thurber stipa in weight and regrowth may have resulted from the ability of this species to resist moderate moisture stress by reduction of transpiration rather than entering dormancy or 
storing carbohydrate reserves. Clipping of the tops of Thurber stipa after 5 weeks of moisture stress was undoubtedly more detrimental to this species due to a higher proportion of the leaves still being physiologically active.

Results of the second experiment were essentially the same as the first. The only notable difference was the slightly larger size of plants at the beginning of the 5-week moisture stress period.

\section{Conclusion}

Greater knowledge of the effects of pre-conditioning of plants to resist environmental stresses would better enable us to interpret plant-environment relations. Resistance or tolerance to moisture stress is influenced by soil productivity level, temperature, and moisture availability. Within limits, growing conditions less than optimum tend to produce plants that are able to tolerate greater moisture stress. Application of knowledge on the effect of pre-conditioning of plants to resist or withstand moisture stress should be considered in efforts to establish plants in areas where availability of moisture is a major concern.

\section{Literature Cited}

Levitr, J. 1956. The hardiness of plants. Academic Prcss Inc., New York, New York. 278 p.

McAlister, D. F. 1944. Determination of soil drought resistance in grass seedlings. J. Amer. Soc. Agron. 36:324336.

OPPenheimer, H. R. 1960. Adaptation to drought: Xerophytism. In Plant-water relationships in arid and semiarid conditions. Unit. Nat. Ed. Sci. and Cult. Org., Paris. p. 105-138.

SCHLATTERER, E. F. 1968. Establishment and survival of three native grasses under natural and artifical conditions. Ph.D. Disscrtation. Univ. of Idaho, Moscow, Idaho. 105 p.

Wallace, T. 1961. The diagnosis of mineral deficiencies in plants by visual symptoms. 2nd. ed. Chemical Publishing Co., New York. 125 p. 